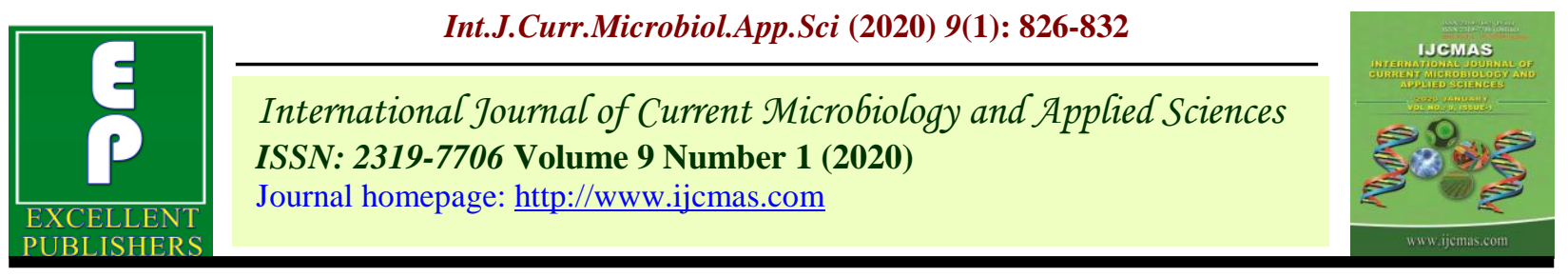

Original Research Article

https://doi.org/10.20546/ijcmas.2020.901.089

\title{
Genetic Variability, Correlation and Path coefficient analysis for Yield and Quality traits in Wheat (Triticum aestivum L.)
}

\author{
Priti Kumari*, Nitish De, Anand Kumarand Anjali Kumari \\ Department of Plant Breeding and Genetics, Bihar Agricultural University, Sabour \\ (Bhagalpur)-813210, Bihar, India \\ *Corresponding author
}

\begin{tabular}{|l|}
\hline Ke y w o r d s \\
Triticumaestivum \\
$\begin{array}{l}\text { L., Genetic } \\
\text { variability, } \\
\text { Correlation } \\
\text { coefficient and path } \\
\text { analysis }\end{array}$ \\
\hline Article Info \\
\hline $\begin{array}{l}\text { Accepted: } \\
\text { 15 December } 2019 \\
\text { Available Online: } \\
\text { 20 January 2020 }\end{array}$ \\
\hline
\end{tabular}

\section{A B S T R A C T}

The present study was aimed to estimate the extent of genetic variability for grain yield \& its components, genetic association, path coefficient analysis in thirty two diverse genotypes of hexaploid wheat (Triticum aestivum L.) at wheat section of Bihar Agricultural University, Sabour during Rabi season 2017-18.High values of phenotypic and genotypic coefficients of variation were higher for important traits including seed yield per plant, 1000-grain weight per spike, respectively. High heritability were recorded for zinc content, iron content,1000-grain weight, grain yield per plant, days to maturity, grain weight per spike, days to $50 \%$ flowering and biological yield. High heritability coupled with high genetic advance were recorded for 1000-grain weight, grain yield per plant grain weight per spike and biological yield indicating that these characters are governed by additive gene effects and directional selection for these traits would be more effective . Grain yield per plant showed positive and significant association with grain weight per spike, biological yield, harvest index, 1000 grain weight, days to maturity and grain yield per plant and positive and significant association with days to 50\% flowering, number of effective tillers per plant and it was significantly and negatively associated with protein content and iron content. Path analysis revealed that biological yield had highest direct positive effect on grain yield followed by harvest index, grain weight per spike, number of effective tillers per plant, protein content and days to $50 \%$ flowering would be quite effective in improving grain. The present study has clearly indicated the need for giving due weight age to grain weight per spike, biological yield, harvest index, 1000 grain weight and grain yield per plant for improving grain yield in wheat. The above mention traits should be given due emphasis for future wheat genetic improvement because they possess high genetic variance, heritability coupled with high genetic correlation among themselves which may yield high genetic advance under proper selection pressure in a breeding programme. 


\section{Introduction}

Wheat (Triticum aestivum L.) is a hexaploid $(2 \mathrm{n}=6 \mathrm{x}=42=$ AABBDD genomes), annual and self-pollinated cereal which is grown worldwide. It belongs to tribe "Triticeae" of the family "Gramineae". Wheat was one of the first domesticated food crops which was evolved in the Fertile Crescent of the Middle East and has become a basic staple food of the present day human population (As stated by Mergoum et al., 2009). Today, wheat is grouped among the big three cereal crops of the world with its high tons of grain yield being harvested annually (Shewry, 2009). The major wheat producing countries are China, India, USA, Russian Federation, Canada, Australia, etc. Cultivation spread to the Near East by about 9000 years ago when hexaploid bread wheat made its first appearance (Feldman, 2001). Wheat has been described as the 'King of cereals' because of the acreage it occupies, high productivity and the prominent position holds in the international food grain trade. The record production in the country during last few years has enabled India to attain the position of being second largest producer of the wheat in the world. Wheat covers 225.06 million ha area, 739.96 million metric tons production and productivity was 3.28 million ton/ ha (FAO STAT., 2016). India covers 30.72 million ha area, 97.44 million tons production and productivity $3172 \mathrm{~kg} / \mathrm{ha}$. Bihar state covers 20.95 million ha area, 47.18 million tons production and productivity was $2252 \mathrm{~kg} / \mathrm{ha}$ (Directorate of Economics and Statistics. 2016-17).

Yield is complex trait; therefore, we have to find out which components contribute more to yield. The estimates of correlation coefficients alone may be often misleading due to mutual cancellation of component characters. So, study of correlation coupled with a path analysis is more effective tool in the study of yield contributing characters (Mahajanet al., 2011). Path coefficient analysis is an important technique for partitioning the correlation coefficient into direct and indirect effect of the causal components on the complex component. The adequate information on extent of variability may also be helpful to improve the yield by selecting the yield component traits (Mehandi et al., 2013).

\section{Materials and Methods}

The experimental materials consisted of thirty two genotypes of wheat were grown in a randomized block design with three replications at wheat section of Bihar Agricultural University, Sabour (Bhagalpur), Bihar, India during 2016-17. The observations were recorded on five randomly selected competitive plants from each genotype in each replication on fourteen agromorphological characters viz; days to $50 \%$ flowering, days to maturity, plant height $(\mathrm{cm})$, number of effective tillers per plant, spike length $(\mathrm{cm})$, number of grains per spike,grain weight per spike,1000 grain weight (g), biological yield per plant $(\mathrm{g})$, grain yield per plant, harvest index (\%), protein content, iron content and zinc content. The treatment means for all the characters were subjected to compute the analysis of variance on the basis of model proposed by Panse and Sukhatme (1969). The phenotypic and genotypic coefficients of variation were estimated according to Burton and Devane (1953), heritability, genetic advance and correlation coefficients were analyzed.

\section{Results and Discussion}

The analysis of variance revealed highly significant differences among the genotypes for all the traits studied. This in turn indicated that there was sufficient variability in the material studied, which could be utilized in 
further breeding programme. Similarly, many earlier workers, Bhushan et al., (2013), Degewione et al., (2013), Fellahi et al., (2013), Kumar et al., (2014) and Yadav et al., (2014) reported high variability for different traits in bread wheat which provides ample scope for selecting superior and desire genotypes by the plant breeder for further improvement. The estimates of PCV were found higher than GCV for 1000-grain weight, grain yield per plant and grain weight per spike, this may be due to the non-genetic factor which played an important role in the manifestation of these characters. The characters with high phenotypic coefficient of variation indicated more influence of environmental factors. Therefore, caution has to be exercised during the selection programme, because the environmental variations are unpredictable in nature and may mislead the results. Wide ranges of variance (phenotypic and genotypic) were observed in the experimental material for all the characters under investigation. Heritability (broad sense) estimated for the fourteen character was ranged from 31\% (protein content)to $89 \%$ (days to $50 \%$ flowering). High heritability were recorded for zinc content, iron content,1000-grain weight, grain yield per plant, days to maturity, grain weight per spike, days to 50\%flowering and biological yield. High heritability value for these traits indicated that the variation observed was mainly under genetic control and was less influence by environment. So, these traits may be used as selection criteria for yield improvement in confirmation with the result of earlier workers viz., Islam et al., (2012), Kumar et al., (2014) and Fellahi et al., (2013). Genetic advance as percent of mean was ranged from days to maturity (6.29)to 1000 grain weight(40.85). The highest magnitude of genetic advance as percent of mean was observed for 1000 grain weight, grain weight per spike,, grain yield per plant and biological yield. Heritability and genetic advance are important selection parameters. Heritability estimates along with genetic advance are normally more helpful in predicting the gain under selection than heritability estimates alone (Johnson et al., 1955).The high heritability accompanied with high genetic advance were recorded by 1000 grain weight, grain yield per plant grain weight per spike and biological yield, it indicates that most likely the heritability is due to additive gene effect and selection may be effective in early segregating generation for these traits.. Hence, direct selection can be done through these characters for future improvement of genotypes for higher grain yield. Similar results were also reported by earlier workers (Islam et al., 2012; Singh et al., 2014 and Yadav et al., 2014, Avinashe et al., 2017).

The study of inter-relationship among various characters in the form of correlation is one of the important aspects in selection programme for the breeder to make an effective selection based on the correlated and uncorrelated response. The phenotypic and genotypic phenotypic correlations between grain yield and its component characters are presented in Table 3. Higher magnitude of genotypic correlation helps in selection for genetically controlled characters and give a better response for seed yield improvement than that would be expected on the basis of phenotypic association alone (Robinson et al., 1951).Grain yield per plant showed positive and significant association (Table-3) with grain weight per spike $(0.5724 * *)$ followed by biological yield $\left(0.5180^{* *}\right)$ harvest index $(0.4198 * *) 1000$ grain weight $(0.3106 * *)$ days to maturity $\left(0.3096^{* *}\right)$ and grain yield per plant and positive and significant association with days to $50 \%$ flowering $(0.2509 *)$, number of effective tillers per plant $(0.2024 *)$ and it was significantly and negatively associated with protein content and iron content. Hence selection for traits viz., 
grain weight per spike, biological yield, harvest index , 1000 grain weight and grain yield per plant and number of effective tillers per plant $(0.2024 *)$ could be helpful for the improvement of bread wheat genotypes. These results were in conformity with the findings of Akhilesh et al., (2014), Hassani et al., (2017), Singh et al., (2017), Obsa et al., (2017).

The path coefficient studied the cause and effect and also studied relationship between the variables which is differentiated the association into direct and indirect effect through other dependent variables. Path coefficient analysis provides an effective way of finding out of direct and indirect sources of correlations. The results are given in Table 4, which reveals that the biological yield had highest direct positive effect on grain yield followed by harvest index, grain weight per spike, number of effective tillers per plant, protein content and days to $50 \%$ flowering. The highest negative direct effect was being observed for iron content ($0.1438)$. These results were in conformity with Tsegaye et al., (2012), Kumar et al., (2014), Tejbir Singh (2016), Phougat et al., (2017). This justifies that the presence of true relationship between these characters and grain yield, there by direct selection through these characters would result reasonable effect on grain yield. The present study showed the presence of considerable variability among the tested wheat genotypes and the possibility of improving yield and other desirable characters through selection. The above mention traits viz., grain weight per spike, biological yield, harvest index, 1000 grain weight, grain yield per plant and number of effective tillers per plant should be given due emphasis for future wheat genetic improvement because they possess high genetic variance, heritability coupled with high genetic correlation among themselves which may yield high genetic advance under proper selection pressure in a breeding programme.

Table.1 Analysis of variance for fourteen quantitative characters in thirty two genotypes

\begin{tabular}{|c|c|c|c|}
\hline \multirow[b]{2}{*}{ Characters } & \multicolumn{3}{|c|}{ Mean sum of square } \\
\hline & $\begin{array}{c}\text { Replication } \\
\text { d.f }=2\end{array}$ & $\begin{array}{c}\text { Treatment } \\
\text { d.f }=\mathbf{3 1}\end{array}$ & $\begin{array}{c}\text { Error } \\
\text { d.f }=62\end{array}$ \\
\hline Days to $50 \%$ flowering & 0.4479 & $157.951 * *$ & 5.942 \\
\hline Days to maturity & 18.010 & $60.429 * *$ & 7.752 \\
\hline Plant height & 114.190 & $160.317 * *$ & 52.503 \\
\hline No of effective tillers/plant & 3.003 & $4.285 * * *$ & 1.217 \\
\hline Spike length & 0.0436 & 3.162 & 0.913 \\
\hline No of grain/spike & 77.276 & $139.280 * *$ & 37.273 \\
\hline Grain weight/ spike & 0.268 & $1.368 * * *$ & 0.138 \\
\hline 1000 grain weight & 40.303 & $268.391 * *$ & 24.499 \\
\hline Biological yield & 66.700 & $243.264 * *$ & 35.114 \\
\hline Grain yield/plant & 6.700 & $34.210 * *$ & 3.456 \\
\hline Harvest index & 48.000 & $99.132 * *$ & 22.314 \\
\hline Protein content & 0.230 & $2.255 *$ & 0.948 \\
\hline Iron content & 0.004 & $20.023 *$ & 1.436 \\
\hline Zinc content & 1.135 & $17.572 *$ & 1.122 \\
\hline
\end{tabular}


Table.2 Phenotypic correlation of fourteen characters in Wheat

\begin{tabular}{|c|c|c|c|c|c|c|c|c|c|c|c|c|c|}
\hline Characters & $\begin{array}{l}\text { Days to } \\
\text { maturity }\end{array}$ & $\begin{array}{l}\text { Plant } \\
\text { ht. }\end{array}$ & $\begin{array}{l}\text { No of } \\
\text { effective } \\
\text { tiller/plant }\end{array}$ & $\begin{array}{l}\text { Spike } \\
\text { length }\end{array}$ & $\begin{array}{l}\text { Grain/s } \\
\text { pike }\end{array}$ & $\begin{array}{l}\text { Grain } \\
\text { wt./spike }\end{array}$ & $\begin{array}{l}1000 \\
\text { grain } \\
\text { wt. }\end{array}$ & $\begin{array}{l}\text { Biologic } \\
\text { al yield }\end{array}$ & $\begin{array}{l}\text { Harvest } \\
\text { index }\end{array}$ & $\begin{array}{l}\text { Protein } \\
\text { content }\end{array}$ & $\begin{array}{l}\text { Iron } \\
\text { content }\end{array}$ & $\begin{array}{l}\text { Zinc } \\
\text { content }\end{array}$ & $\begin{array}{l}\text { Grain yield } \\
\text { per plant }\end{array}$ \\
\hline $\begin{array}{l}\text { Days to } 50 \% \\
\text { flowering }\end{array}$ & $0.6996 * *$ & $0.2097 *$ & $-0.2620 * *$ & -0.0820 & 0.0981 & 0.1144 & 0.0335 & 0.1997 & 0.0353 & 0.0470 & 0.1283 & 0.0754 & $0.2509 *$ \\
\hline $\begin{array}{l}\text { Days to } \\
\text { maturity }\end{array}$ & & 0.1390 & $-0.2547 *$ & 0.0397 & 0.1149 & 0.1629 & 0.1450 & $0.2228 *$ & 0.1436 & 0.0677 & 0.0014 & 0.1561 & $0.3096 * *$ \\
\hline Plant ht & & & 0.0601 & $0.2598 *$ & 0.0025 & 0.0799 & 0.1114 & $0.2515 *$ & 0.0626 & -0.0405 & 0.2935 & -0.0806 & 0.1875 \\
\hline Spike length & & & & & -0.1355 & 0.1552 & $0.2736 * *$ & 0.0744 & 0.0410 & 0.1913 & 0.0288 & -0.0835 & 0.0870 \\
\hline Grain/spike & & & & & & -0.0424 & 0.0520 & 0.0543 & 0.1403 & 0.1650 & -0.2182 & -0.0330 & 0.2005 \\
\hline $\begin{array}{l}\text { Grain wt. } \\
\text { /spike }\end{array}$ & & & & & & & $0.3605 * *$ & $0.2125^{*}$ & $0.3560 * *$ & -0.1742 & -0.0542 & -0.0255 & $0.5724 * *$ \\
\hline 1000 grain wt. & & & & & & & & 0.0904 & $0.3416 * *$ & 0.0170 & 0.1568 & 0.0756 & $0.3106 * *$ \\
\hline $\begin{array}{l}\text { Biological } \\
\text { yield }\end{array}$ & & & & & & & & & -0.2339 & -0.2413 & -0.0258 & 0.2794 & $0.5180 * *$ \\
\hline Harvest index & & & & & & & & & & -0.0095 & -0.1088 & -0.0322 & $0.4198 * *$ \\
\hline $\begin{array}{l}\text { Protein } \\
\text { content }\end{array}$ & & & & & & & & & & & 0.1245 & 0.0004 & -0.0212 \\
\hline Iron content & & & & & & & & & & & & 0.2744 & -0.1750 \\
\hline Zinc content & & & & & & & & & & & & & 0.1160 \\
\hline
\end{tabular}


Table.3 Direct and indirect effect of different yield and quality characters on grain yield in wheat

\begin{tabular}{|c|c|c|c|c|c|c|c|c|c|c|c|c|c|}
\hline Characters & $\begin{array}{c}\text { Days to } \\
50 \% \\
\text { flowering }\end{array}$ & $\begin{array}{l}\text { Days to } \\
\text { maturity }\end{array}$ & Plant ht. & $\begin{array}{c}\text { No of } \\
\text { effective } \\
\text { tiller/plant }\end{array}$ & $\begin{array}{l}\text { Spike } \\
\text { length }\end{array}$ & $\begin{array}{l}\text { Grain/ } \\
\text { spike }\end{array}$ & $\begin{array}{c}\text { Grain } \\
\text { wt./spike }\end{array}$ & $\begin{array}{c}1000 \\
\text { grain wt. }\end{array}$ & $\begin{array}{l}\text { Biological } \\
\text { yield }\end{array}$ & $\begin{array}{l}\text { Harves } \\
t \text { index }\end{array}$ & $\begin{array}{l}\text { Protein } \\
\text { content }\end{array}$ & $\begin{array}{l}\text { Iron } \\
\text { content }\end{array}$ & $\begin{array}{c}\text { Zinc } \\
\text { content }\end{array}$ \\
\hline $\begin{array}{l}\text { Days to } 50 \% \\
\text { flowering }\end{array}$ & 0.1508 & 0.1055 & 0.0316 & -0.0395 & -0.0124 & 0.0148 & 0.0172 & 0.0050 & 0.0301 & 0.0053 & 0.0071 & 0.0193 & 0.0114 \\
\hline $\begin{array}{l}\text { Days to } \\
\text { maturity }\end{array}$ & 0.0160 & 0.0229 & 0.0032 & -0.0058 & 0.0009 & 0.0026 & 0.0037 & 0.0033 & 0.0051 & 0.0033 & 0.0016 & 0.0000 & 0.0035 \\
\hline Plant ht & 0.0005 & 0.0003 & 0.0023 & 0.0001 & 0.0006 & 0.0000 & 0.0002 & 0.0003 & 0.0006 & 0.0001 & -0.0001 & 0.0007 & -0.0002 \\
\hline $\begin{array}{l}\text { No of effective } \\
\text { tiller/plant }\end{array}$ & -0.0626 & -0.0609 & 0.0144 & 0.2390 & 0.0352 & 0.0796 & 0.0144 & 0.0392 & 0.0109 & -0.0134 & 0.0088 & -0.0035 & -0.0123 \\
\hline Spike length & 0.0000 & 0.0000 & -0.0001 & -0.0001 & -0.0006 & 0.0001 & -0.0001 & -0.0002 & 0.0000 & 0.0000 & 0.0001 & 0.0000 & 0.0000 \\
\hline Grain/spike & -0.0035 & -0.0041 & -0.0001 & -0.0118 & 0.0048 & -0.0355 & 0.0015 & -0.0018 & -0.0019 & -0.0050 & -0.0059 & 0.0077 & 0.0012 \\
\hline Grain wt/spike & 0.0332 & 0.0473 & 0.0232 & 0.0174 & 0.0450 & -0.0123 & 0.2901 & 0.1046 & 0.0616 & 0.1033 & -0.0505 & -0.0157 & -0.0074 \\
\hline 1000 grain wt & -0.0009 & -0.0037 & -0.0029 & -0.0042 & -0.0070 & -0.0013 & -0.0093 & -0.0257 & -0.0023 & -0.0088 & -0.0004 & -0.0040 & -0.0019 \\
\hline Biological yield & 0.1101 & 0.1228 & 0.1387 & 0.0252 & 0.0410 & 0.0300 & 0.1172 & 0.0498 & 0.5514 & -0.1290 & -0.1331 & -0.0143 & 0.1541 \\
\hline Harvest index & 0.0159 & 0.0647 & 0.0282 & -0.0253 & 0.0185 & 0.0632 & 0.1604 & 0.1539 & -0.1054 & 0.4506 & -0.0043 & -0.0490 & -0.0145 \\
\hline Protein content & 0.0082 & 0.0117 & -0.0070 & 0.0064 & -0.0332 & 0.0286 & -0.0302 & 0.0030 & -0.0418 & -0.0016 & 0.1734 & 0.0216 & 0.0001 \\
\hline Iron content & -0.0184 & -0.0002 & -0.0422 & 0.0021 & -0.0041 & 0.0314 & 0.0078 & -0.0226 & 0.0037 & 0.0156 & -0.0179 & -0.1438 & -0.0395 \\
\hline Zinc content & 0.0016 & 0.0033 & -0.0017 & -0.0011 & -0.0018 & -0.0007 & -0.0006 & 0.0016 & 0.0060 & -0.0007 & 0.0000 & 0.0059 & 0.0261 \\
\hline $\begin{array}{l}\text { Correlation } \\
\text { with grain } \\
\text { yield/plant }\end{array}$ & 0.2509 & 0.3096 & 0.1875 & 0.2024 & 0.0870 & 0.2005 & 0.5724 & 0.3106 & 0.5180 & 0.4198 & -0.0212 & -0.1750 & 0.1160 \\
\hline Partial $\mathbf{r}^{2}$ & 0.0378 & 0.0071 & 0.0071 & 0.0484 & 0.0000 & -0.0071 & 0.1660 & -0.0080 & 0.2857 & 0.1891 & -0.0037 & 0.0252 & 0.0025 \\
\hline
\end{tabular}




\section{References}

Arya, V.K., Singh, J., Kumar, L., Sharma, A.K., Kumar, R., Kumar, P., Chand, P. 2017. Character association and path coefficient analysis in wheat (Triticum aestivum L.). Indian Journal of Agricultural Research, 51 (3): 245-251.

Choudhary, M.A., Ali, M., Subhani, G.M. and Khalid, I. 2000. Path coefficient analysis for water use efficiency evapotranspiration efficiency and some yield related traits in wheat. Pakistan Journals of Biological Science, 3(2): 313-317.

Dabi, A., Mekbib, F., Desalegn, T. 2016. Estimation of Genetic and Phenotypic Correlation Coefficients and Path Analysis of Yield and Yield Contributing Traits of Bread Wheat (Triticum aestivum L.) Genotypes. International Journal of Natural Resource Ecology and Management. 1(4): 145-154.

Hassani, I., Marker, S. and Lal, G.M. 2017. Inter-relationship studies among grain yield and its component characters in wheat (Triticum aestivum L.). Journal of Pharmacognosy and Phytochemistry, 6(4): 186-191.

Hussain, A.I. and Shakor, E.F. 2012. Heritability, variability, genetic correlation and path analysis for quantitative traits in durum and bread wheat under dry farming conditions. Mesopotamia journal of Agriculture 40 (4).

Khan,M.H. and Dar, A.N. 2009. Correlation and Path coefficient analysis of some quantitative traits in wheat. African Crop Science Journal, 18(1):9-14.

Moetamadi, S.A., Mohtasham, P., Mohammadi, M., Khaniki, GRB., Karimizadeh, R.A. 2015. Assessment of correlation and path analysis in wheat under drought stress. Journal of Biodiversity and Environmental Sciences. 6(5): 178-183.

Mohanty, S., Mukherjee, S., Mukhopadhyaya, S.K., Dash, A.P. 2016.Genetic Variability, Correlation and Path Analysis of Bread Wheat (Triticum aestivum L.) Genotypes under Terminal Heat Stress. International Journal of Bio-Resource \& Stress Management, 7(6): 1232-1238.

Rajpoot, P., Verma, O.P., Rajbahadur. 2013. Genetic Variability, Correlation and Path Coefficient Analysis for Yield and it's Contributing Traits in Wheat (Triticum aestivum L.). International Journal of Science and Research: 23197064.

Kumar, S., Kumar., Anand and Jha, P.B. 2014. Choice of advance heterogeneous population for wheat (Triticum aestivum L.) improvement. The Bioscan 11(2).

\section{How to cite this article:}

Priti Kumari, Nitish De, Anand Kumarand Anjali Kumari. 2020. Genetic Variability, Correlation and Path coefficient analysis for Yield and Quality traits in Wheat (Triticum aestivum L.). Int.J.Curr.Microbiol.App.Sci. 9(01): 826-832

doi: https://doi.org/10.20546/ijcmas.2020.901.089 